\title{
Phenomenon of independent candidates in the regional elections in Slovakia from 2001 to 2017
}

UDC 342(1-32)(437.6)《2001/2017»:342.843.1 DOI https://doi.org/

10.24195/2414-9616-2018-2-55-60

Marcel Martinkovič

PhD in Political Sciences,

Head at the Department

of Political Science

at Trnava University,

Hornopotočná 23, Trnava,

Slovak Republic

\begin{abstract}
The constant growth of support for independent candidates in regional and local elections in the Slovak Republic can be called the manifestation of the current crisis in the functioning of political parties in Slovakia. Such a tendency to support the so-called public and independent candidates has several legitimate reasons. They still hinder the effective functioning of political parties, especially at the level of regional self-government. Factors which negatively limit the process of decentralization of public administration in the Slovak Republic are the following ones: the creation of a single constituency at the level of parliamentary elections, the further undevelopment of regional and local party structures and low voter turnout. The following risk factors at the regional level of large territorial units are the low level of voter awareness, the ownership structure of regional media and its impact on media content, low level of professionalism of regional resources and the lack of effective public control over representatives of local self-government bodies. The oligarchic structure of parties, as well as the low level of party members' base, combined with the high level of corruption behavior of political elites, in the future, leads to greater support for so-called independent candidates. Paradoxically, but the risk of increasing support for so-called independent candidates is the reduction of public control, the low level of predictability of political decisions and the spread of non-transparent and corrupt behavior of representatives of large territorial units.

Key words: regional elections in Slovakia, decentralization, political parties, oligarchization, independent candidates.
\end{abstract}

Introduction. Decentralization of self-government structures is an important aspect in increasing the opportunities for improving the quality of citizens' participation in the management of political institutions. The process of decentralization and the creation of regional self-government structures in the Slovak Republic was carried out by a broad coalition government, Mikulas Dzurinda (SDK, SDL', SMK, SOP; 1998-2002) ${ }^{1}$. His goal was to improve and bring regional and local authorities closer to citizens and to increase the transparency and effectiveness of the functioning of public administration. The emergence of regional self-government bodies and their parliaments (higher territorial units, the so-called «VUC», or also «administrative districts»), had to deal more tangibly and effectively with the specific problems of certain regions of Slovakia. At the same time the process of decentralization had to bring decision-making for citizens and increase final civilian control over political decisions. However, the problem of the decentralization of public administration Iduring the first government of Dzurinda was based on the already implemented changes concerning the administrative-territorial division of Slovakia, carried out by the previous third government, Vladimir Meciar (HZDS, SNS, ZRS; 1994-1998) ${ }^{2}$. The government of Meciar in this process of decentralization of public administration was first to ignore the boundaries of natural

1 The SDK (Slovak Democratic Coalition) was in fact a party coalition of such parties as the Christian Democratic Movement $(\mathrm{KDH})$, the Democratic Union (DU), the Democratic Party (DS), the Social Democratic Party of Slovakia (SDSS) and the Green Party of Slovakia. A large constitutional coalition was formed: SDL - Left Democrats Party, SMK-MKP - Hungarian Coalition Party, SOP Public Consent Party.

2 HZDS - Movement for Democratic Slovakia, SNS - Slovak National Party and Society of Workers of Slovakia. historical regions. The distribution of some towns and villages between Zemplin and Spis in Eastern Slovakia is an example of it. This first major change in the territorial division of Slovakia, which resulted in the creation of 8 territories, also negatively limited other processes of decentralization during the first government of Dzurinda. The Slovak experience of regional decentralization, which was carried out from the «top», from the political center, however, reveals its limitations and possible political risks in 16 years.

Currently, the biggest disadvantage of the process of decentralization is the low level of legitimacy of these regional structures. Their creation was the result of a political agreement between the intention of the government majority (the parties SDK, SDL', SMK, SOP) to create more regions that copied the historically established regions and the requirements of the then parliamentary opposition (HZDS, SNS). The opposition proposed to divide the self-governing regions in accordance with the already adopted model of the 8 edges. The previous project of the representative of the Slovak government on public administration reform in the first government of Dzurindu Viktora Niznanskeho was based on the idea of decentralization at the level of 16 , and later 12 regional municipalities. However, the governmental project of decentralization with the number of 12 regional municipalities first met with disapproval from the coalition party of the Party of Left Democrats, and later the parties of the parliamentary opposition (HZDS, SNS). The reason for their negative attitude to the presented model of territorial regions was the intention to create the so-called Komarnansky administrative district. Despite the fact, that he took into account this historical aspect, it was unacceptable for them, since 
most of the Hungarian speaking residents of the Slovak Republic were concentrated on its territory. Thus, within the framework of the growing nationalist split in the Slovak party system, the government's decentralization project, precisely because of concerns about the dominance of the Hungarian minority in the Komarnansky district, was not politically possible. In the end, parliament through the disunity of government deputies in 2001 adopted a model that the opposition preferred - 8 VUC. He confirmed the scatteredness of the Hungarian-speaking SMK voters in several self-governing regions (Bratislava, Nitra, Banska Bystrica and Kosice regions). Thus, this model of decentralization was based on the administrative boundaries of the eight edges (1994-1998), existing since the third government of Meciar.

Goal and tasks. The reminder of the genesis of the emergence of regions is of great importance in the context of the modern search for an answer to the question why regional elections had the lowest level of voter participation (after the elections to the European Parliament). After 16 years of experience, we can, from a longer distance, think of the positive and especially negative consequences and risks of decentralization without taking into account the natural boundaries of the regions.

To the risk factors of decentralization and the emergence of regional municipalities (after the last regional elections on November 4, 2017), we can primarily attribute the fact that citizens do not identify themselves according to this regional structure. Until today, they do not realize the importance and influence of political decisions of self-government in the sphere of primary and secondary education, medical and social institutions, transportation and the like. Low interest in regional elections and further decision-making that takes place at the level of regional self-government also affects the decrease in the legitimacy of regional bodies decisions of the local self-government. An integral part of this development in Slovakia is also the loss of public and civil control over the adoption of decisions in regional parliaments.

At the beginning, the main objective of our investigation was to find out how the participation in the regional elections (VUC) is connected and the support of the so-called independent candidates is increasing. To find out whether there is a closer relationship between these factors and what are the consequences of increasing support for independent candidates.

Results of the Investigation. The growth of state support for non-partisan candidates in local elections in local elections has been noticeable since 2005. The trend of public support for independent candidates has several reasons. This led to the fact that more than twice as many candidates were elected to the regional municipalities as regional representations during the latest regional elections, compared to the last elections of this type of 2013 (73 independent candidates' seats). In general, in the regional elections with local self-government in 2017, historically, the largest number of independent candidates was chosen, in particular 161 mandates. This number corresponds to $39.42 \%$ of the mandates of the total number of 416 deputies of all VUC [10]. It's a paradox, however, the parliamentary level of party politics has the greatest impact on this growing trend of supporting independent candidates, since it is most evident from the point of view of the public. The centralization of political parties, which was caused by the change in the electoral law to the Slovak Parliament by the third Meciar government before the elections in 1998, led to the introduction of deforming aspects that hitherto negatively affect the functioning of political parties in the Slovak Republic. We have in mind, in particular, the introduction of one national party candidate and the creation of one constituency of 150 seats during the parliamentary elections. This change led to an increase in the elitization of parties and the creation of parties with a strong charismatic or populist leader. In general, such a change in Meciar electoral legislation in the Parliament of Slovakia has a negative impact on the development of the structured political system ${ }^{3}$ [3, s. 50] and the process of consolidation of political parties in the Slovak Republic.

The existence of a single electoral district at the parliamentary elections for the moment also negatively limits the development of party structures at the local and regional levels. Parties are not required to systematically develop their activities at the local and regional levels. To function in parliament, they have enough of a narrow circle of party elites and regional structures. The motivation to actively develop party structures from below has thus disappeared from the activities of political actors in Slovakia. As a result, there is a noticeable crisis of confidence and activity of parties, often interrelated at the national level with separate groups of economic interests through party elites. In the present situation of the oligarchization of politics in the Slovak Republic, the fact that the number of parties that were definitely established in the party system were clearly separated from the initial, already entrenched subjects, have even smaller membership base and a narrower party leadership than the original parties (e. g. SaS, OL'aNO, NOVA, Siet', Kotleba - L'S Naše Slovensko and so on). This would be natural for the new parties, but some of the mentioned parties exist in the Slovak party system for more than a term and, despite this, have not yet advanced in the development of the lower party structures. The risk factor in this situation, when parties across the country are represented mainly by one leader and a narrow 3 The main criterion for the consolidation and stabilization of the
party system, according to G. Sartori, which is related to the extent
to which programming parties are created regarding parties with a charismatic leader. 
group of his supporters, is that they quickly become an oligarchic structure ${ }^{4}$ [4, s. 150-153], in which the influence of locally lower levels is minimized. In the process of developing the internal democratic environment of the parties there are no primary elections, inner-party referendum on the main issues of party orientation and state cooperation. This fact proving the low level of participation and competence of local and regional party structures in the activities of political actors in general subsequently affects the reduction of the functionality of parties. This is reflected in their inability to unite public interest, communicate with citizens, ensure the organization of management and its effective control, and, in particular, generate enough professional and experienced political leaders. In a situation where, in the Slovak party system for a long time, parties lose their personnel resources, in particular, their functionality is reduced, which is necessary for the quality management activities. This fact is also reflected in the increase in citizens' distrust of political parties. In such an environment, the negative trends that affect the oligarchization of party structures are further exacerbated. Thus, the cycle of loss of confidence in parties as the organizational structures necessary for the functioning of institutions of modern democracy and at the regional level is coming to an end. The legality of the established parties is also reduced by the reluctance of the leaders to display political responsibility on suspicion of corrupt behavior of party representatives. This actual failure of the leaders and leadership of the parties leads to a loss of confidence in the entire democratic regime and its institutions. The reason why such a situation occurs in all established parties in Slovakia (L'S-HZDS, SNS, KDH, SDKÚ-DS, Smer-SD, Most-Híd, SaS, etc.), who have executive responsibility is a quantitatively narrow party leadership and had number of active parts. At this stage of development of parties there are just a few experienced people who want to enter party politics at a lower regional and local levels. As a result of these development tendencies, at the level of the national party system, there are customers of the party spirit, leading to the so-called «clientelistic parliamentarism» and «defective democracy» [1, s. 215-216]. This model of democracy is characterized, besides a number of corruption cases, by a high degree of instability in the executive branch. The further instability of political parties affects the permanent party demarcation and the emergence of new participants capable of making themselves known in the elections (for example, in the 1998 elections SMK, SOP; 2002 - Smer, ANO; 2010 - Most-Híd, SaS; 2012 OL'aNO; 2016 - Kotleba - L'S Naše Slovensko, SME RODINA - Boris Kollár, Siet').

This negative trend in the development of parties is expressed in the reduction of confidence in them by

${ }^{4}$ «The Iron Law of the Oligarchy» in the context of the functioning of democracy and party structures. the results of public opinion research. An attempt to change this trend, in which politics turns into a theater for populists, is observed in regional and local elections. At the above-mentioned levels of self-government, with the lack of trust in parties, the spread of the idea is associated with so-called "non-political policy". Such an idealistic view subsequently generates the already mentioned increase in the number of independent candidates. The efforts of individual groups of citizens to improve the functioning of decision-making processes at these levels are reflected in the creation of local political organizations. Such development can be regarded as a certain positive differentiation of the forms of political participation. In contrast, there is a tendency to increase the state support of independent candidates (NEKA). This leads to a lot of political risks, especially in the sphere of lobbying and corruption. The reason is that their decisions and relations with target groups are much more difficult to control compared to candidates from political parties. Thus, in the process of constant strengthening of their representation in self-government bodies, the policy becomes more and more non-transparent both for the public and for the media. Therefore, the opportunity for the public to effectively monitor their activities is actually decreasing. This development of the growing support of independent candidates since 2001 is confirmed by the statistical results of individual regional elections.

In the first regional elections in large territorial units in 2001 with a total participation of $22.61 \%$ of voters in all major territorial units, only 18 independent candidates were elected. In the Bratislava region, 1 independent candidate was elected as a deputy, 3 independent candidates in the Zhilinsky district, 1 in the Bansko-Bystrica region, 5 in the Presov district and 8 independent candidates in the Kosice region. The final result for independent candidates was $4.48 \%$ of all elected candidates for self-government in the Slovak Republic. In the Trnava, Trencin and Nitra regions, independent candidates did not receive a single mandate.

In the second election in large territorial entities in the year 2005, due to the low voter participation of $18.02 \%, 39$ independent candidates were elected in all major territorial units. In the Bratislava region, 2 deputies were elected, Trnava - 5, Trencin - 3, Zilina - 5, Banska Bystrica -5, Presov - 12 and Kosice regions -7 independent candidates. This amounted to $9.46 \%$ of all elected candidates for self-government bodies. In the Nitra region, independent candidates have not received a single mandate again. Despite the decrease in voter turnout in regional elections, the positions of independent candidates in all regions of the government increased, with the exception of Nitra and Kosice regions,

In the third election in large territorial units in 2000 with a higher participation in the elections (compared to 
the 2005 elections), the number of voters was $22.90 \%$. In total, 55 independent candidates in all major territorial units were elected to the regional self-government bodies. This was significantly more than the regional elections in the year 2005 and it was $13.48 \%$ of the total number of elected deputies of regional self-government bodies. In the Bratislava region, there was a recession, since only one independent candidate was elected as a deputy. At the same time, 6 independent candidates won in the Trnava region, in Trencin - 10, Nitra - 3 independent candidates, in Zilina edge - 11 Banska Bystrica - 5, Presov regions - 6, and in Kosice region deputies became 13 independent candidates. Thus, with this election, there has been a recession in the number of elected independent candidates, namely in the Bratislava region by 1 independent candidate and in the Presov region by 6 independent candidates compared to the 2005 elections. In Banska Bystrica region, the number of independent candidates who won in the elections in comparison with the above-mentioned elections did not change and remained at the level of 5 deputies.

In 2013, there was again a recession in participation in regional elections compared to the elections in 2009. Participation reached the level of $20.11 \%$ of the total number of voters. A large number of independent candidates were elected in the elections to regional self-government bodies. In all large territorial units, the total number of independent candidates who were elected by the deputies was 73 mandates. So, on the whole, the number of independent deputies increased by $17.89 \%$ of all deputies elected to the local government. In the Bratislava region, the number of independent candidates increased by 6 deputies, in the Trnava region the situation did not change, that is, independent candidates received 6 deputy seats; in the Trencin region, independent candidates received 11 seats; in the Nitra region, 4 independent candidates were elected, in Zilina region - 16, in the Banska Bystrica region - 13 deputies. In Presov region, compared to the elections in 2009 , the situation did not change, that is, 6 independent candidates got into the Chamber of Deputies. Only in the Kosice region the number of successful independent candidates compared to the 2009 elections decreased from 13 to 11.

In the last regional elections in 2017 there was an increase in the number of voters compared to the elections in 2013. Participation reached $29.95 \%$ of the total number of voters, mainly because of an intensive information campaign concerning the competencies of large territorial units in national socio-political media. The second factor of higher participation compared to the long-term average at the level of $20.91 \%$ by 2013 was due to the mobilizing campaign of the majority of parliamentary parties against candidates antisystemic and extremist ${ }^{5}[2, \mathrm{~s} .78]$ of the party "Kotleba - L'S Naše Slovensko". Despite this, there were more independent candidates for the regional

\footnotetext{
5 This value is used by us in the context of the analysis of antisystemic parties, and this political force has attributes of ideological antisystemic nature.
}

self-government bodies, namely 161 mandates. In the Bratislava region, the number of independent candidates increased by 25 deputies, independent candidates received 14 seats in the Trnava region, in the Trencin region -27 , in the Nitra region of the parliament 15 independent candidates were elected, in the Zilina region - 25, in the Banska Bystrica region - 22 . In Presov region independent candidates received 22 seats, and in Kosice region the number of elected independent candidates increased to 16 mandates. Thus, the total number of independent candidates was $39.42 \%$ of all deputies elected to regional self-government bodies.

The above mentioned information on participation in regional elections in the Slovak Republic from 2001 to 2017 confirms the growth of the success trend of independent candidates, in contrast to candidates from parliamentary parties approved at the national level [5-10] ${ }^{6}$. This development also applies to parties that are considered stabilized at the local level as well (for example, KDH, SNS, Smer-SD, SMK-MKP, Most-Híd) ${ }^{7}$. From the above mentioned results, we can state that the participation of citizens in five local government elections is sinusoidal and does not copy the constantly growing trend of supporting independent candidates. Elections regularly alternate with maximum and minimum participation, with voters' participation not exceeding $22.9 \%$. The exception is the last election in November 2017. However, before these elections, a short-term media campaign was held in most of the national media, aimed at disseminating awareness of the competence and activities of large territorial units. One of the factors that led to an increase in the participation in the elections in 2017 to $29.95 \%$ is, in particular, the pre-election efforts of opposition parliamentary parties to create a unified political approach to Smer-SD. Their combination consisted of publicly presenting themselves at the regional level as a significant political alternative. No less important reason was the mobilization activity of all pro-democratic parliamentary parties against the efforts of the anti-system party "Kotleba - L'S Naše Slovensko" secretly get into the municipal policy organs.

Despite the fact that the electoral system in the Parliament of the Slovak Republic and the electoral system in the regional municipalities is not the same (the first is a proportional electoral system of party

6 The $\downarrow$ vector tends to recession of independent deputies of large territorial units in the total \% of the representatives of selfgovernment - the province in comparison with the previous term of office. Vector $\uparrow$ expresses the growing share of independent deputies of large territorial units in the total number of votes of the self-government representatives - the region in comparison with the previous term of office.

7 The only exception is SMK-MKP, which, after the section of the initial voter base of the primary "Strany mad'arskej koalície Magyar Koalíció Pártja» for the elections in 2010 (between «MostHíd» and «Stranu mad'arskej komunity - Magyar Közösség Pártja») is capable of receiving the necessary support within the southern districts and municipalities of Slovakia, but so far could not exceed $5 \%$ of the barrier to the Parliament of the Slovak Republic. 
documents with a high level of proportional influence due to a low quorum for joining the parliament, and the second - with a broad proportion with the broad possibility of the participation of independent candidates); we can make a conclusion that there is a correlation between the crisis in the functionality of established parties at the parliamentary level and the increase in support for independent candidates at the level of self-government. Despite the mentioned above differences between two types of elections, it can be argued that these development processes are interrelated. The growth of public distrust of the established parties at the national level correlates at the level of regional elections with an increase in the support of independent candidates, regardless of voter turnout. This phenomenon can be reflected as another risk in the development and consolidation of the party system in Slovakia.

The results of the analysis of participation in elections to regional self-government bodies are based on the level of self-government of the regions as the one, which significance and the positive impact on the opportunities for regional development citizens do not realize yet. This is due to the fact that a certain level of self-government was created primarily by the decision of the central political elites, namely from the top without special demand from citizens and taking into account historical regional features. As a result, citizens are still not guided by the competence of large territorial units and do not have adequate political abilities for meaningful organized participation in regional local self-government. After the abovementioned deforming change in the law on parliamentary elections by the coalition of HZDS, SNS and ZRS before the elections of 1998, after which Slovakia became a single electoral district, an important legal criterion was removed, which creates pressure on the development of the lower structures of political parties.

In contrast to this deforming law and criticism from the opposition in 1998 (KD, DÚ, DS, SMK, SDL') at this stage the law was not changed even after the creation of the first government of M. Dzurinda (SDK, SDL, SMK, SOP). A partial amendment to the Election Law has become an obstacle to an integrated and effective decentralization of public administration. Although institutionalized decentralization was implemented first, the broad government coalition of M. Dzurinda did not change the electoral law, which still limits the development of important organizational structures of parties by the existence of one constituency. For this reason, political elites, after 16 years of self-government existence, once again face the question of the significance of decentralization implemented in this way, decentralization, which the citizens have hardly perceived. This indicates a low participation of voters in regional elections.

So, the Slovak model of decentralization is an example of the fact that decentralization should not be a solution to optimize the activities of political institutions, but should provide better civil and political control. The reason is that for a long time there is no real interest of the elites in order to conduct it in a comprehensive manner, and from the public there is no demand and awareness of the significance of such a regional interdepartmental body of local self-government.

Conclusions. The constant decline in trust in political parties that are established at the level of the state party system is displayed at the level of regional elections, increasing the support of independent candidates. Today we are witnessing that many members of parliamentary parties eventually decide to participate in elections to regional missions as independent candidates. The reason for this is the desire to avoid suspicion about the opacity and corrupt behavior of party elites. However, the negative result of this development is shown by the public in the form of reducing the transparency and manageability of regional policies. At the beginning of the decentralization of public administration and self-government, the above-mentioned tendency to increase the support of independent candidates seemed to be one of the possible ways out of the crisis of the party system that began in Slovakia.

However, nowadays, even after 25 years after the regime change in Slovakia, there is no law on lobbying in Slovakia, an effective and efficient law on the financing of political parties, and other independent monitoring institutions, it may happen that an increase in support for independent candidates and an institutional crisis parties can significantly help stabilize political inequality and even more closely interrelate the interests of economic pressure groups and make political decisions. The reason for such practical risks for the functioning of democratic institutions is that the behavior of individuals at the level of self-government often remains outside the public interest and effective control. This fact allows more effective promotion of interests of influential groups. In case the above mentioned development will be continued, the Slovak Republic may be among the countries with the so-called «defective democracy».

\section{REFERENCES:}

1. Klíma M. Od totality $\mathrm{k}$ defektní demokracii. Praha : SLON, 2015. 368 s.

2. Kubát M. Politická opozice $v$ teorii a středoevropské praxi. Praha: Dokorán, 2010. 200 s.

3. Sartori G. Srovnávací ústavní inženýrství. Praha : Slon, 2001. $238 \mathrm{~s}$.

4. Sartori G. Teória demokracie. Bratislava: Archa, 1993. $512 \mathrm{~s}$.

5. Štatistický Úrad SR. URL: http://volby.statistics.sk/ osk/osk2001/webdata/slov/obsah.htm.

6. Štatistický Úrad SR. URL: http://volby.statistics.sk/ osk/osk2005/slov/results/tab2.jsp.htm. 
7. Štatistický Úrad SR. URL: http://volby.statistics.sk/ osk/osk2009/sr/tab2.jsp@lang=sk.htm.

8. Štatistický Úrad SR. URL: http://volby.statistics.sk/ osk/osk2013/VUC/Tabulka1_sk.html.
9. Štatistický Úrad SR. URL: http://volby.statistics.sk/ osk/osk2017/sk/data01.html.

10. Štatistický Úrad SR. URL: http:// volby.statistics.sk/osk/osk2017/sk/data03.html.

\section{Феномен незалежних кандидатів на регіональних виборах у Словаччині (2001-2017 рр.)}

\section{Марцел Мартинкович}

доктор політології, завідувач касредри політології

Трнавського університету

вул. Горнопоточна, 23, м. Трнава, Словацька Республіка
Актуальність дослідження зумовлена характером електоральних процесів у Словацькій Республіиі, починаючи з 2000-х рр. Постійне зростання підтримки незалежних кандидатів на регіональних та місцевих виборах у Словацькій Республіці можна назвати проявом нинішньої кризи у функціонуванні словацьких політичних партій. Така тенденція зростання підтримки так званих громадських і незалежних кандидатів має кілька причин. Мета та завдання статті полягають у визначенні політологічного змісту френомена незалежних кандидатів на словацьких регіональних виборах. Під час дослідження було застосовано компаративний, інституційний, емпірико-статистичний методи.

Основним результатом статті став політологічний аналіз факторів, які дотепер перешкоджають есрективному фрункціонуванню політичних партій, особливо на рівні регіонального самоврядування. До інститучійних чинників, які обмежують процес децентралізації громадського управління у Словацькій Республіці, належать такі фрактори: створення єдиного виборчого округу на рівні парламентських виборів, нерозвиненість регіональних і місцевих партійних структур та низький рівень явки виборців. Похідними фракторами ризику на регіональному рівні великих територіальних одиниць є низький рівень поінфрормованості виборців, власницька структура регіональних ЗМІ та ії вплив на медіа-контент, низький рівень профресіоналізму регіональних ресурсів і відсутність ефективного громадського контролю за представниками органів місцевого самоврядування. Олігархічна структура партій у поєднанні з високим рівнем корупційної поведінки політичних еліт у подальшому зумовлюють більшу підтримку електоратом так званих незалежних кандидатів. Парадоксально, але ризиком збільшення підтримки так званих незалежних кандидатів є зменшення громадського контролю, низький рівень передбачуваності прийняття політичних рішень та поширення непрозорої і корупційної поведінки представників великих територіальних одиниць.

Ключові слова: регіональні вибори у Словаччині, децентралізація, політичні партії, олігархізація, незалежні кандидати. 